\title{
CELLAOPTIMALIZÁLT NAPELEMEK
}

\author{
Lipták Róbert \\ Ph.D. hallgató, Miskolci Egyetem, Fizikai és Elektrotechnikai Intézet, \\ Elektrotechnikai és Elektronikai Intézeti Tanszék \\ 3515 Miskolc, Miskolc-Egyetemváros, e-mail: elkrobi@uni-miskolc.hu \\ Balázs Péter \\ villamosmérnök alapszakos hallgató, Miskolci Egyetem, Fizikai és Elektrotechnikai Intézet, \\ Elektrotechnikai és Elektronikai Intézeti Tanszék \\ 3515 Miskolc, Miskolc-Egyetemváros, e-mail: balazs.peter98@gmail.com
}

\begin{abstract}
Absztrakt
A tanulmány a napelemeknél jelentkezö, esetleges környezeti hatások következtében fellépö teljesitménycsökkenést vizsgálja. A hagyományos napelemes rendszerek teljesitményét sokszor visszavetik a napelemek sorba kapcsolásából, azaz sztringbe szervezéséböl adódó hátrányok is. A szemmel nem mindig észrevehetö hibák feltárására alkalmas a hökamerás hibadiagnosztika, mellyel a legtöbb esetben magyarázható a probléma forrása, de ez a vizsgálat nem mutatja folyamatosan az esetleges hibákat, illetve időigényes a folyamat. Az egyenáramú (DC) optimalizálóval felszerelt modulok használatával ugyanis minimálisra csökkenthetök a szennyezödésekböl, a napelemek különbözöségéböl vagy akár a napelemek meghibásodásából adódó teljesitményveszteségek. A cellaoptimalizált napelemek terjedése a közeljövöben még nagyobb mérteket fog ölteni, mert gazdaságos alternativa és mindemellett az optimalizálás révén élettartam növelö hatásúak.
\end{abstract}

Kulcsszavak: napelem, cellaoptimalizált napelem, napelemek teljesítmény csökkenése, napelemek hatékonyságának növelése

\begin{abstract}
This paper presents the reduction in performance of solar cells due to possible environmental effects. The performance of conventional solar systems are often offset the disadvantages arising from the solar cells in series, that string in the organization of it. Thermal camera fault diagnosis is suitable for detecting faults which not noticeable to the eye, which in most cases can explain the source of the problem, but this examination does not continuously show possible errors or the process is timeconsuming. By using modules equipped with a direct current (DC) optimizer, power losses due to dirt, differences in solar cells or even solar cell failure can be minimized. The proliferation of celloptimized solar cells will be even greater in the near future because they are an economical alternative and, in addition, have a life-enhancing effect through optimization.
\end{abstract}

Keywords: solar cell, cell-optimized solar cell, decrease solar cell performance, increase solar cell efficiency

\section{Bevezetés}

A napelem panelek müködése során az egyes cellákat érintő árnyékhatás következtében a tiszta, árnyékhatástól mentes celláknál is tapasztalható teljesítménycsökkenés. Az utóbbi évtized kutatásai arra 
irányultak, hogy az árnyékolt, illetve meghibásodott cellák automatikus kiiktatása révén az ép, tiszta cellák teljesítménye ne csökkenjen. Ennek eredményeként olyan napelem paneleket hoztak létre, ahol cella szintü optimalizálás valósul meg. A cellaoptimalizált, vagy okos napelemek elterjedése ugyan még várat magára, azonban a jövő napelemes rendszere a hatékonyság- és az élettartamnövelés érdekében az okos napelemek alkalmazását fogja megkívánni.

A napelemeket érő sugárzás csak kis része alakul villamos energiává, többsége hő formájában jelentkezik az eszközben. A napelemek hatásfoka álltalában 15-20\%, a sugárzás maradék nagy része a hőveszteség. Ez a hőmennyiség sajnos elkerülhetettlen, és káros az energiatermelésre, valamint a napelem élettartamára is. Éppen ezért a hőmérsékletnövekedés elkerülése a legföbb cél. A modulok üzemi hőmérséklete függ a rajtuk keletkező hőtől, a környezet hőmérsékletétől és a környezet felé leadott hőmennyiségtől. A gyártók a napelem adattábláján adják meg a hőmérsékletre vonatkozó adatokat. Ezt álltalában $25^{\circ} \mathrm{C}$-on, $1 \mathrm{~kW} / \mathrm{m}^{2}$ körülmények között határozzák meg. Itt általában feltüntetik a normál üzemi hőmérsékletet (NOCT), és a hőmérsékleti együtthatókat (Bodnár, 2019).

Ezek azt mutatják meg, hogy a panel hőmérsékletének $1{ }^{\circ} \mathrm{C}$-al való emelkedése milyen százalékban befolyásolja a különböző paramétereket. A valós körülmények között álltalában jóval magasabb hömérsékleten dolgoznak a megadottnál, ezért fontos a ténylegesen várható értékekkel tisztában lenni a rendszerek tervezésénél (Bodnár, 2019; Honsberg and Bowden 2017a).

A keletkező hő több tényeztőtől is függ:

1. A modul felületének visszaverő képessége.

2. A napelem munkapontja és hatékonysága.

3. A fény cellákon kívüli abszorpciója.

4. Az infravörös sugárzás elnyelése a cellákban.

5. A cellák elhelyezkedésének sürüsége.

A Felületről visszaverődő fény nem járul hozzá a termeléshez, ugyanakkor melegíti a napelemet. Ezt minél jobban minimalizálni kell, ennek érdekében a gyártók az üveg felületet visszaverődés gátló anyaggal vonják be, ezzel csökkentve a hatást. A napelem munkapontja a beérkező fény elnyelődésétől függ abban az esetben, ha a modul nem rövidzárként vagy nyitott kapcsokként müködik, mert ekkor az elnyelt energia hőként jelenik meg rajta. A panel hőmérsékletében közbe játszik a cellákon kívüli terület nagysága, ennek anyaga, színe és abszorpciós tényezője. A kis energiájú fény nem képes elnyelődni a hasznos rétegekben és energiává alakulni, ellenben a napelem hátsóbb részein abszorbál és hővé alakul. A cellák elhelyezkedésének sürüsége befolyásolja a keletkező hő mennyiségét. Minél nagyobb a cellák sűrüsége annál nagyobb az egységnyi felületen keletkező hő (Honsberg and Bowden, 2017a).

\section{A kiinduló probléma: a cellák különbségei (Mismatch Effects)}

Jelentős gondot okoz a sorosan összekapcsolódó cellák paramétereinek különbségei, abban az esetben, ha a valamely cella tulajdonságai eltérőek bizonyos szempontból a többihez képest (1. ábra). Két tökéletesen azonos cella soha nem készül. Tökéletes körülmények között két sorba kapcsolt napelemes cellán egy azon rövidzárási áram és üresjárási feszültség mérhető. A gyártás során a cellákat külön tesztelik és mérik teljesítményüket AM1.5 standard feltételek mellett, majd pedig sorozatokba, csoportokba rendezik őket, ám így is adódhat, hogy a tökéletesnek minősített és azonos csoportba tartozó cellák tulajdonságai valóságos természeti körülmények között idővel megváltoznak. Ezen felül számos oka lehet a cellák elektromos paraméter eltérésének, erre legegyszerübb és leggyakoribb a beárnyéko- 
lás, vagy éppen az eltérő életartamcsökkenés, károsodás (Honsberg and Bowden, 2017b; EU-Solar, 2016).

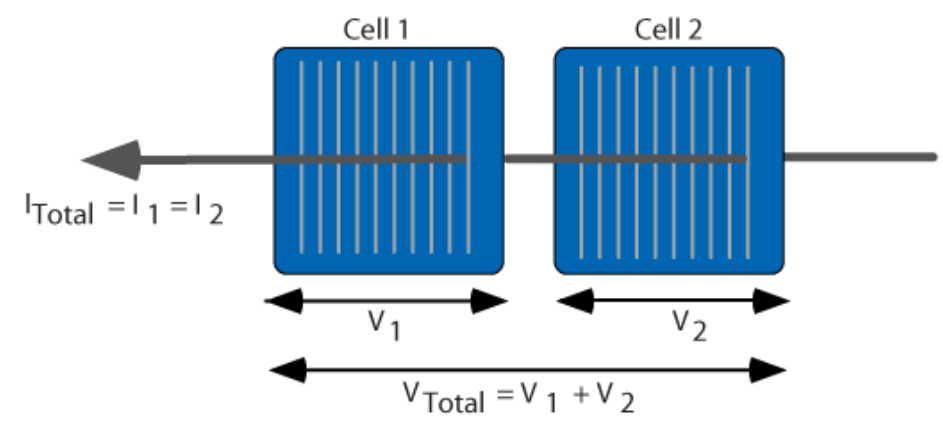

1. ábra. Cellák árama és feszültsége sorba kapcsolva.

A cellák feszültség és áram értékei egyaránt megváltoznak az őket érő hatások bármelyikének megváltozásával. Ilyen hatások lehetnek pl. az árnyékhatások. Ha a sorosan kapcsolt cellák közül valamelynek csökken a feszültsége, az alapvetőleg a modul kapocsfeszültségét gyengíti és ez által az összteljesítményt is. Mivel az áramkörben egyazon értékü áram folyhat, így a gyengébb (pl. részben leárnyékolt) cella kevesebb áramot produkál, mint a többi, ezáltal rajta disszipálódik a többi cella által megtermelt energia és ezzel lehúzza a többi épp cella teljesítményét is. Mindez hömérsékletkülönbséget eredményez a napelem panelen belül. A hőmérsékleteloszlás, illetve a cellánkénti hőmérséklet ismeretében megmondható, hogy mely celláknál léptek fel problémák, így azok a cellák az okos napelemeknél kiiktathatók, ezzel megszüntetve a problémát (Honsberg and Bowden, 2017b; EU-Solar, 2016). Még egy hibátlanul müködő panel esetében is tapasztalhatók hőmérsékletdifferenciák az egyes cellák között, azonban azok értéke $15{ }^{\circ} \mathrm{C}$-nál kisebb értéket képviselnek. Amennyiben egy napelempanelen belül $15^{\circ} \mathrm{C}$-nál nagyobb hőmérsékletdifferencia tapasztalható, ott minden bizonnyal károsodott cellákkal találkozhatunk. Extrém esetekben a hőmérsékletdifferencia meghaladhatja a 30, de a kár az $50{ }^{\circ} \mathrm{C}$ hőmérsékletet is. Ilyen ezesetben a napelempanel életútjának vége felé jár (Bodnár, 2019).

A szabadtéren elhelyezkedő eszközök esetében az árnyék napfüggő, helyzete és mérete változó, úgynevezett vonuló árnyék. Ha a napelemes rendszer előtt, a nap irányából tárgyak vannak, akkor nagy valószínüséggel az árnyékuk a napelem felületére képződik le, de lehetnek a napelem felületén lévő tartós árnyékot képző anyagok is, mint például a felületi szennyeződések, amelyeket a levegőben lévő szálló porok lerakódása, vagy az állati ürülék felületre tapadása jelent. Az árnyékolás az egyik legnagy problémája a napelemes rendszereknek. Az árnyékhatás időbeli lefolyása hőmérsékleti tranziensjelenséget okoz a napelemen, amely következtében a napelempanel és az azokat felépítő cellák villamos paraméterei időben dinamikusan változnak. A cellák hőtehetetlensége 1-2 perces időállandóval jellemezhetö, azonban a nagy méretü panelek esetében akár 10-15 perc is lehet (Bodnár, 2018; Bodnár, 2017). Időben ettől gyorsabban bekövetkező árnyékhatás-változás, ciklikus beárnyékoltság és árnyékmentesség esetében a hőmérsékleti tranziensfolyamatok csak részlegesen tudnak lejátszódni, hatásuk pedig a villamos paraméterekre nézve szintén ciklikus.

\section{A Hot Spot jelenség kezelése, a BayPass dióda szerepe}

Hot Spot, azaz forró pont melegedésröl akkor beszélünk, ha az elözőkben leírtak alapján valamely kis terület a napelemen árnyékba kerül, vagy egyéb sérülés, ok miatt nem tud a többi ép cellához hasonló- 
an energiát elöállítani. Ekkor a sztring többi ép cellája által megtermelt energia a hibás rész ellenállásán hő formájában jelentkezik. Ez nagyobb probléma, mint a teljesítmény hozamának vesztése. Ez a nagy disszipálódó teljesítmény a (leárnyékolt, hibás) kis területet túlságosan felmelegíti, úgynevezett hot-spot keletkezik, amely visszafordíthatatlan károkat okoz a napelemben. Ilyenek például a cella vagy üvegtörés, repedés, forrasztások fémes kontaktok olvadása, deformálódása, napelem öregedés. A napelemeket érö árnyékhatások szabad szemmel is megfigyelhetők, de a napelemekre gyakorolt hatásuk vizsgálatához infravörös termográfiát kell alkalmaznunk. Ily módon a felmelegedett cellák és területek jól láthatóak, hőkamerás képeken. Összefoglalva bizonyos szempontból ellentmondó hatással állunk szemben. Az árnyék általánosságban a hömérsékleti terhelést csökkenti, ez kedvező hatás a napelem számára. A negatív hőmérsékleti együttható miatt, az alacsonyabb hőmérséklet hozamnövekedést jelent. Ugyanakkor ez besugárzás csökkenést okoz, amely energiahozam csökkenéssel jár, ami kedvezőtlen hatás az energiatermelésre (EU-Solar, 2016; Honsberg and Bowden, 2017c).

A napelem felületére vetülő, csak részletesen takaró mozgó árnyék a rendszer müködésében igen zavaró és jelentős villamos aszimmetriát okoz, mely a napelem tönkremeneteléhez vezethet. Ezen felül a Hot spotok kialakulása javarészt az árnyékolásnak köszönhető, amely súlyos károkat okoz a napelemek számára.

A bypass diódák legfontosabb szerepe a cellák megvédése a túlmelegedéstől. Okai lehetnek a forró pontok nagy teljesítménysürüség a cella egy kis pontjában, egyéb sérülés vagy árnyékhatások. A beárnyékolt cellák nem fognak tudni ugyanolyan hatékonyan müködni, mint amelyeket teljes egészében ér a napfény. Ebben az esetben a beárnyékolt cella terhére lesz a napelemes rendszernek. Ez pedig a felmelegedését és végül a kiégését eredményezheti (Napelem.blog.hu, 2016; Boudewijn et al., 2017). Erre ad megoldást a bypass dióda, amely egyfajta áthidalóként müködhet a rendszerben (2. ábra).

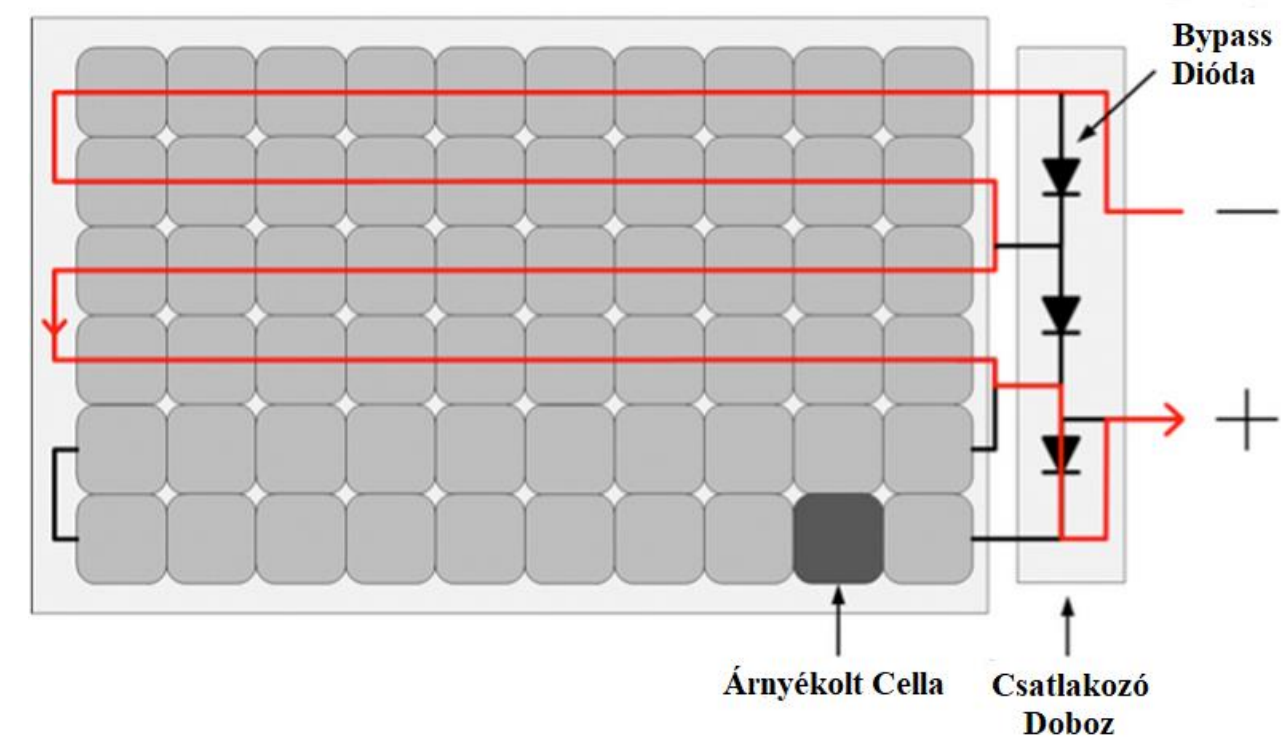

2. ábra: Bypass dióda müködése.

Párhuzamosan kapcsolódnak az alsztringekhez, és egymással soros összeköttetésben állnak. Normál üzemben záróirányban vannak bekötve a cellákhoz képest, így nyitott áramkörként viselkedik. A részben sérült vagy árnyékba került napelem cellák polaritás váltásával a velük sorba kötött és müködő többi napelem cellának köszönhető az eredő feszültség megemelkedik. A félvezető anyagok p-n átme- 
netei igencsak érzékenyek a záró irányú feszültségre és emiatt végleg tönkre mehetnek. A bypass dióda, ennek elkerülése végett nyitóirányúvá válik és a kritikus cella vagy cellafüzért kikerülve elvezeti az áramot a többi müködő rész felé, közben a beárnyékolt cellán csak a bypass dióda nyitóirányú (kb. $0,6 \mathrm{~V}$ ) feszültsége marad, ami a p-n átmenetet már nem károsítja. Ennek köszönhetően a teljes cellafüzér teljesítménye helyett csak egy töredéke esik ki (Napelem.blog.hu, 2016; Boudewijn et al., 2017).

\section{A cellaoptimalizálás lényege}

A napelemes rendszerek hibáinak megelőzése és észrevétele érdekében, fontos az optimális rendszerkörülmények ismerete, mint referencia. Ezen paraméterek rendszeres ellenőrzése, értéken belül tartása.

Nem mellőzhető az időszakos karbantartási munkálatok, tisztítások, ellenőrzések elvégzése sem. Ilyenek a napelemek tisztítása, felületi sérülések ellenőrzése, földi telepítésnél talaj és szerkezet rendben tartása, villamos részek mérése, ellenőrzése, stb. A szemmel nem mindig észrevehető hibák feltárására alkalmas, a munkámban bemutatott hőkamerás hibadiagnosztika, mellyel a legtöbb esetben magyarázható a probléma forrása. Egyre több megoldás születik ezen, hibalehetőségek kiküszöbölésére. A következőkben egy ilyen példát mutatok be (Majoros, 2016; Mysolar Knowledge Center, 2019).

Az utóbbi évek során az egyenáramú (DC) optimalizálók a napelemes rendszerek egyre fontosabb alkotórészévé kezdtek válni, mind háztartási, mind ipari és erőmüvi méretekben. Az ilyen technológiával felszerelt modulok használatával ugyanis minimálisra csökkenthetők a szennyeződésekből, a napelemek különbözőségéből vagy akár a napelemek meghibásodásából adódó teljesítményveszteségek. A hagyományos napelemes rendszerek teljesítményét sokszor visszavetik a napelemek sorba kapcsolásából, azaz sztringbe szervezéséből adódó hátrányok (Majoros, 2016; Mysolar Knowledge Center, 2019).
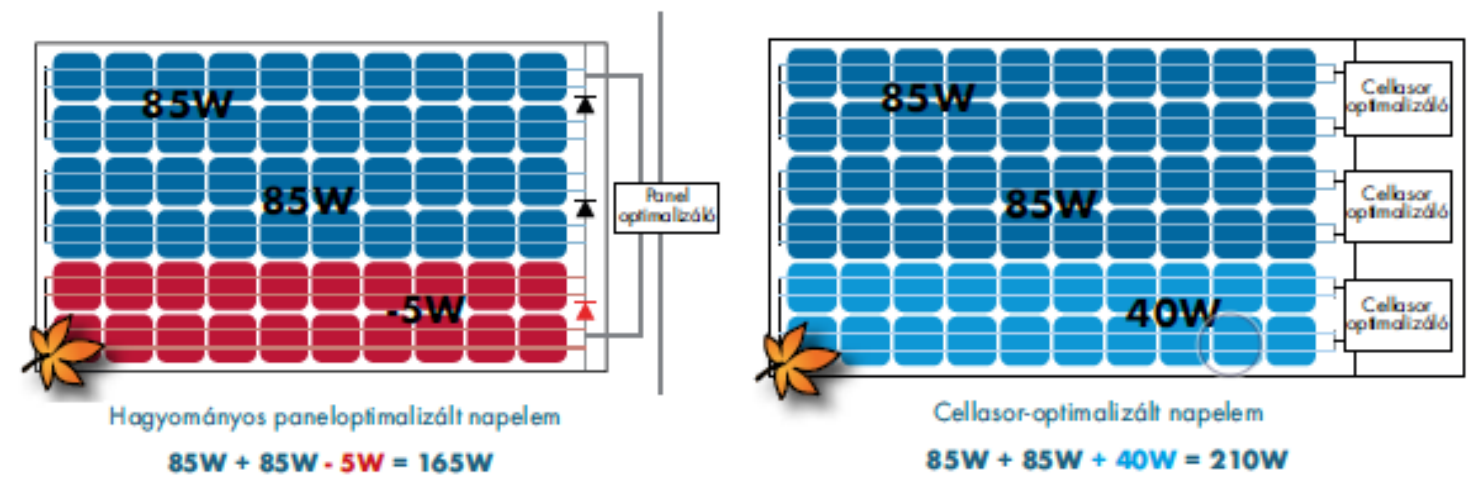

\section{3. ábra. Hagyományos és cellasoroptimalizált napelem.}

A cellasor-optimalizálók a gyengébb cellasorok áramát erősítik fel addig, hogy azok passzoljanak az erősebbek áramához, így kiküszöbölve a hagyományos rendszerekben előálló egymást akadályozó hatást. A cellasor optimalizálók maximális teljesítményü munkapontba történő szabályozás (MPPT) funkciója együttmüködik az inverter MPPT-jével, így biztosítva, hogy a rendszer minden körülmények között a lehetö legjobb teljesítményt nyújtsa. A panelek csatlakozó dobozában három cellasoroptimalizáló váltja ki a hagyományos panelekben megtalálható három bypass diódát. Amikor a bypass dióda aktív, akkor az egész cellasor termelése elvész, még akkor is, ha annak csupán egy kis része van árnyékban. Az aktív diódán átfolyó áram hőt fejleszt és ez a terhelés idővel a dióda elhasználódásához vezet. A bypass dióda tönkremenetele a cellasor termelésének folyamatos kiesését eredményezi. A 
Maxim által optimalizált napelemekben (3. ábra) a bypass diódák helyett intelligens IC-k vannak. Az árnyékolt cellasor hozzáad az egész paneléhez annyi energiát, amennyit csak tud úgy, hogy közben nem befolyásolja a többi cellasor müködését (Majoros, 2016; Mysolar Knowledge Center, 2019).

\section{5. Összefoglalás}

A korszerü és nagy ütemben fejlődő iparágnak köszönhetően az energiatermelés optimalizálása és a berendezések ellenállósága egyre kedvezőbb, de emellett lényeges a meglévő rendszerek időszakos állapotfelmérése is. A cellaoptimalizált napelemek terjedése a közeljövőben még nagyobb mérteket fog ölteni, mert gazdaságos alternatíva és mindemellett az optimalizálás révén élettartam növelő hatásúak. Mivel a napelemes rendszerek telepítése költséges, így hosszútávú müködésre és ez alatt mihamarabbi megtérülésre hivatottak.

\section{Köszönetnyilvánítás}

A cikkben ismertetett kutató munka az NTP-SZKOLL-20-0022 azonosítószámú „Fókusz'21 - Középpontban a közösség digitális kompetenciák fejlesztése által" projekt keretében valósult meg az Emberi Erőforrások Minisztériuma és az Emberi Erőforrás Támogatáskezelő támogatásával.

\section{Irodalom}

[1] Bodnár, I. (2019). Napelemek müködésének alapjai, a napelemes villamosenergia termelés elmélete és gyakorlati megvalósitása. Miskolci Egyetem Micropress Kft. p. 108. ISBN 978615-00-456-65.

[2] Majoros, L. (2016). Jinko Maxim okos napeleme, a teljesítmény optimalizálás csúcsa.

[3] Mysolar Knowledge Center (Jul 1, 2019) What is PID (Potential Induced Degradation) in solar? https://www.mamibot.com/post/what-is-pid-potential-induced-degradation-in-solar

[4] Bodnár, I. (2018). Electric parameters determination of solar panel by numeric simulations and laboratory measurements during temperature transient. Acta Polytechnica Hungarica, 15(4), 59-82.

[5] Honsberg, C., Bowden, S. (2017a). Temperature effects, Heat Generation in PV Modules. https://www.pveducation.org/pvcdrom/modules-and-arrays/heat-generation-in-pv-modules

[6] Bodnár, I. (2017). Napelem hőmérsékletfüggésének kísérleten és szimuláción alapuló vizsgálata. Jelenkori társadalmi és gazdasági folyamatok, XII(4), 195-206. https://doi.org/10.14232/jtgf.2017.4.195-206

[7] Honsberg, C., Bowden, S. (2017b). Interconnection Effects, Mismatch for Cells Connected in series. $\quad$ https://www.pveducation.org/pvcdrom/modules-and-arrays/mismatch-for-cellsconnected-in-series

[8] EU-Solar (2016). Napelemek és napelemes árnyékhatások esetében. https://www.eusolar.hu/blog/napelemek-es-napelemes-arnyekhatasok-eseteben/

[9] Honsberg, C., Bowden S. (2017c). Interconnection Effects, Hot spot heating. https://www.pveducation.org/pvcdrom/modules-and-arrays/hot-spot-heating

[10] Napelem.blog.hu (2016). A bypass dióda. https://napelem.blog.hu/2016/02/10/a_bypass_dioda

[11] Boudewijn, B. Pannebakker, Arjen, C. de Waal, Wilfried G. J. H. M. van Sark (29 May 2017). Photovoltaics in the shade: one bypass diode per solar cell revisited. https://onlinelibrary.wiley.com/doi/full/10.1002/pip.2898 https://doi.org/10.1002/pip.2898 